\title{
Interleukin-1 Receptor Type 2
}

National Cancer Institute

\section{Source}

National Cancer Institute. Interleukin-1 Receptor Type 2. NCI Thesaurus. Code C38914.

Interleukin-1 receptor type 2 (398 aa, $\sim 45 \mathrm{kDa}$ ) is encoded by the human IL1R2 gene.

This protein plays a role in both interleukin-1 binding and the inhibition of signaling. 